\title{
50
}

\section{POLA PEMBINAAN NARAPIDANA WANITA OLEH LEMBAGA PEMASYARAKATAN DALAM PERSPEKTIF PEKERJAAN SOSIAL}

\author{
Oleh \\ Puti Halimah, Dessy Hasanah Siti A., \& Hery Wibowo \\ Email: \\ (halimah.puti@gmail.com; desyhasanahsta@yahoo.co; hery_fortune@yahoo.com
}

\begin{abstract}
ABSTRAK
Artikel ini membahas tentang tema yang menurut penulis masih tabu di masyarakat, khuhusnya Indonesia, yaitu perempuan dan lembaga pemasyarakatan. Artikel ini di latar belakangi dengan kasus kriminal yang terus meningkat jumlahnya dari tahun ke tahun, serta peningkatan yang cukup signifikan terjadi pada narapidana wanita, contohnya tercatat pada Lembaga Pemasyarakatan Wanita Klas IIA, Bandung, Jawa Barat, Lembaga Pemasyarakatan ini telah melebihi kapasitas penampungan atau over capacity. Seperti yang dilansir dalam website resmi Kementerian Hukum dan HAM, jumlah penghuni Lembaga Pemasyarakatan Wanita Klas IIA, Bandung berjumlah 371 orang, sedangkan kapasitas seharusnya adalah 325 orang. Banyaknya jumlah narapidana wanita yang terus meningkat ini tidak lepas dari peran dari lembaga pemasyarakatan,. Lembaga pemasyarakatan yang ditunjuk oleh kementerian hukum dan HAM untuk mengatur, mengawasi serta menjamin hak hidup dari narapidana. Berkaitan dengan Lembaga Pemasyarakatan, maka tidak lepas pula dari pola pembinaan yang dirancang untuk mengembalikan keberfungsian sosial narapidana pasca masa tahanan. Pola pembinaan yang disusun oleh pihak Lembaga Pemasyarakatan tidak luput dari peran pebimbing kemasyarakatan atau pekerja sosial koreksional.Peran pembimbing kemasyarakatan adalah untuk mengawasi seluruh kegiatan narapidana dari pagi hingga malam hari. Kelebihan jumlah narapidana wanita pada Lapas Klas IIA Tangerang, menyebabkan peran pembimbing kemasyarakatan kurang optimal, tercatat dengan jumlah narapidana yang melebihi kapasitas Lapas, satu orang pembimbing kemasyarakatan berbanding dengan 25 narapidana. Dalam pekerjaan sosial, ada metode yang dapat digunakan untuk mengatasi keterbatasan tersebut, salah satunya adalah metode social group work, dimana metode ini dapat meudahkan para narapidana untuk saling bertukar cerita,apalagi ditambah dengan kesamaan latar belakang serta jenis kelamin sehingga membuat narapidana wanita lebih jujur dengan apa yang diungkapkan.
\end{abstract}

Kata Kunci : narapidana, wanita, Lembaga pemasyarakatan, program pembinaan

\section{Pendahuluan}

Permasalahan wanita yang dikatakan sebagai 'tiang negara' dewasa ini telah menjadi suatu hal yang banyak diperbincangkan. Dahulu, sebelum berkembang masa emansipasi, wanita dianggap hanya bisa melakukan pekerjaan rumah tangga dan tidak selayaknya menempati posisi strategis dalam bidang pekerjaan, begitu pula anggapan masyarakat luas yang mengatakan bahwa tidak layak seorang wanita melakukan pekerjaan laki-laki dan berbuat kesalahan seperti laki-laki, sehingga ketika mendengar kata 'penjara' atau lembaga pemasyarakatan maka yang terlintas dalam pikiran adalah seorang laki-laki dewasa yang sedang dihukum dengan masa kurungan tertentu. 
Seiring berjalannya waktu, setelah konsep emansipasi yang diartikan sebagai kesetaraan antara laki-laki dan perempuan berkembang, mulai banyak konsep kesetaraan yang dibuat, misalnya pemimpin perusahaan-perusahaan besar bahkan hingga pemimpin negara telah lumrah ditepati oleh perempuan. Dalam bidang kriminalitas, kesalahan-kesalahan yang dilakukan seorang laki-laki dewasa bisa juga dilakukan seorang perempuan, misalnya membunuh, merampok, hingga korupsi. Tuntutan untuk hidup layak dan sejahtera secara financial ataupun emosi pribadi hingga pengaruh lingkungan yang tidak baik merupakan faktor tingginya tindak kriminalitas yang dilakukan perempuan.

Lembaga Pemasyarakatan merupakan unit pelaksana teknis di bawah Direktorat Jenderal Pemasyarakatan Kementerian Hukum dan Hak Asasi Manusia (dahulu Depertamen Kehakiman). Penghuni Lembaga Pemasyarakatan bisa narapidana (Napi) atau warga Binaan Pemasyarakatan tahanan (WBP) bisa juga yang statusnya masih tahanan, maksudnya yang statusnya masih berada dalam proses peradilan dan belum ditentukan bersalah atau tidak oleh hakim. Pegawai Negeri Sipil yang menangani pembinaan narapidana dan tahanan di lembaga pemasyarakatan di sebut dengan petugas pemasyarakatan, atau dahulu lebih dikenal dengan istilah sipir penjara.

Berbicara tentang lembaga pemasyarakatan, maka tidak lepas kaitannya dengan program pembinaan. Lembaga pemasyarakatan berfungsi untuk mengembalikan keberfungsian sosial seorang narapidana hingga masa tahanan mereka selesai, untuk emnegambalikan keberfungsian sosial mereka pasca masa tahanan, pada masing-masing lembaga pemasyarakatan memiliki program pembinaan masing-masing.Untuk 'memulihkan' keberfungsian sosial seorang narapidana maka peran pekerja sosial sangat dibutuhkan untuk membantu hal tersebut.

Artikel ini akan membahas tentang urgensi program pembinaan yang dilakukan oleh lembaga pemasyarakatan khusus wanita, serta bagaimana pekerjaan sosial memandang hal tersebut.

\section{Pembahasan}

\section{Lembaga Pemasyarakatan Wanita}

Lembaga Pemasyarakatan (disingkat LP atau LAPAS) adalah tempat untuk melakukan pembinaan terhadap narapidana dan anak didik pemasyarakatan di Indonesia. Sebelum dikenal istilah lapas di Indonesia, tempat tersebut disebut dengan istilah penjara. Lembaga Pemasyarakatan merupakan Unit Pelaksana Teknis di bawah Direktorat Jenderal Pemasyarakatan Kementerian Hukum dan Hak Asasi Manusia (dahulu Departemen Kehakiman). Penghuni Lembaga Pemasyarakatan bisa narapidana (napi) atau Warga Binaan Pemasyarakatan (WBP) bisa juga yang statusnya masih tahanan, maksudnya orang tersebut masih berada dalam proses peradilan dan belum ditentukan bersalah atau tidak oleh hakim. Pegawai negeri sipil yang menangani pembinaan narapidana dan tahanan di lembaga pemasyarakatan disebut Petugas Pemasyarakatan, atau dahulu lebih dikenal dengan istilah sipir penjara.Lembaga Pemasyarakatan yang selanjutnya disebut LAPAS adalah tempat untuk melaksanakan pembinaan Narapidana dan Anak Didik Pemasyarakatan. Narapidana adalah seseorang yang dipidana berdasarkan putusan pengadilan yang telah memperoleh kekuatan hukum tetap dan menjalani pidana hilang kemerdekaan di LAPAS. Anak didik pemasyarakatan adalah :

a. Anak Pidana yaitu anak yang berdasarkan putusan pengadilan menjalani pidana di LAPAS Anak paling lama sampai berumur 18 (delapan belas) tahun;

b. Anak Negara yaitu anak yang berdasarkan putusan pengadilan diserahkan pada negara untuk dididik dan ditempatkan di LAPAS Anak paling lama sampai berumur 18 (delapan belas) tahun;

c. Anak Sipil yaitu anak yang atas permintaan orang tua atau walinya memperoleh penetapan pengadilan untuk dididik di LAPAS Anak paling lama sampai berumur 18 (delapan belas) tahun. dirampas untuk negara berdasarkan putusan pengadilan. 
Lembaga Pemasyarakatan khusus wanita sendiri berdiri karena intervensi terhadap narapidana wanita harus berbbeda dengan narapidana laki-laki maupun anaik-anak, misalnya seharusnya ada pembeda dalam bentuk lapas serta kegiatan-kegiatan yang dilaksanakan karena banyak beberapa ke-stress-an yang sering dialami kaum perempuan namun tidak dialami kaum lakilaki misalnya stress karena harus meninggalkan anak.

\section{Klien Pekerjaan Sosial Koreksional}

Setting pekerja sosial yang menangani isu lembaga pemasyarakatan serta kriminalitas merupakan setting dari pekerjaan sosial koreksional. Pekrjaan sosial koreksional dapat diartikan sebagai seseorang yang embantu narapidana atau ahanan pada lembaga pemasyarakatan untuk dapat hidup normal kembalki saat bermasyarakat ketika masa tahanan mereka telah habis.

Pekerjaan sosial koreksional, seperti setting pekerjaan osial yang lain juga memeiliki beberapa kategori klien. Ada beberapa kategori dari klien yang menerima perhatian, pertolongan, treatment, dan pengawasan melalui institusi pemerintahan. Beberapa contoh dari klien pekerjaan sosial koreksional, antara lain, seorang klien harus 'layak' dianggap sebagai seseorang yang berurusan dengan hukum. Pada kasus ini seseorang yang disebut 'sakit jiwa' dapat menerima bantuan Negara seperti diberikan proses hukum yang sesuai serta menerima pelayanan rumah sakit khusus, begitu pula dengan anak dengan disabilitas, lansia dan tuna netra harus dilindungi pula oleh hukum yang berlaku. Seorang anak yang memiliki IQ dibawah 70 juga memiliki hak yang sama untuk belajar disekolah umum. Contoh lains, seorang pecandu obat-obatan juga dapat menerima pelayanan yang sama di rumah sakit umum seperti layaknya masyarakat lain. Tidak satupun dari klien tersebut yang benar-benar memiliki 'kerusakan' dalam hubungan mereka dengan masyarakat.

Klien dari pekerjaan sosial koreksional merupakan seseorang yang memiliki kesalahan dalam bermasyarakat dan secara legal bertanggungjawab dengan apa yang telah mereka perbuat. Klien telah melanggar hukum yang berlaku kemudian merusak keteraturan sosial yang telah ada oleh kesalahannya, untuk itu klien dari pekerjaan sosial koreksional adalah mereka yang menginginkan dirinya memperbaiki kesalahannya untuk diterima kembali oleh masyarakat. Salah satu dari klien pekerjaan sosial koreksional adalah narapidana wanita yang ditempatkan pada lembaga pemasyarakatan wanita yang akan dibahas dalam artikel ini.

\section{Konsep Gender}

Gender sebagai alat analisis umumnya dipakai oleh penganut aliran ilmu sosial konflik yang justru memusatkan perhatian kepada ketidakadilan struktural dan sistem yang disebabkan oleh gender. Untuk memperjelas peran analisis gender, kita perlu memahami pradigma di balik gerakan dan teori feminisme. Gerakan feminis pada umumnya mereka mempunyai kesamaan kepedulian, yakni memperjuangkan nasib perempuan. Secara gerakan feminis terdiri dari dua bagian, besar dalam ilmu sosial yakni aliran status quo atau fungsionalisme dan aliran konflik.

Gerakan feminisme merupakan perjuangan dalam rangka mentransformasikan sistem dan struktur yang tidak adil, menuju sistem yang adil bagi perempuan maupun laki-laki. Dengan demikian strategi perjuangan jangka panjang gerakan feminisme tidak sekedar upaya pemenuhan kebutuhan praktis kondisi kaum perempuaan atau dalam rangka mengakhiri dominasi gender dan manifestasinya. Melainkan perjuangan transformasi sosial ke arah penciptaan strutur yang secara fundamental baru dan lebih baik.Feminitas dan maskulinitas mempunyai ideologi yang berbeda dan kontradiktif. Feminitas adalah ideologi yang berciri kedamaian, keselamatan, kasih, dan kebersamaan. Sementara maskulinitas memiliki karakter persaingan, dominasi, eksploitasi, dan penindasan. Dalam perjalanannya maskulinitas mampu berhasil mendominasi dan hegemonic

Pertanyaan apakah dan mengapa ada masalah bagi kaum perempuan yang merupakan akar perdebatan isu perempuan telah memunculkan tanggapan yang sangat beragam. Tanggapan pertama memandang bahwa sesunguhnya tidak ada masalah bagi kaum perempuan sehingga sistem hubungan 
antara laki-laki dan perempuan saat ini adalah yang terbaik dan karena itu kondisi dan posisi kaum perempuan tidak perlu dipersoalkan. Responsi kedua datang dari mereka yang mengangap bahwa saat ini kaum perempuan berada dalam kondisi dan posisi yang ditindas dan dieksploitasi. Setelah kita telaah secara mendalam, perbedaan gender ini ternyata telah mengakibatkan lahirnya sifat dan streotipe yang oleh masyarakat dikanggap sebagai ketentuan kodrati atau bahkan ketentuan Tuhan.

Konsep gender yang telah diterangkan sebelumnya, maka tak lepas kaitannya dengan masalah narapidana perempuan serta program pembinaan yang dijalankan. Contohnya, program pembinaan pada Lapas Klas IIA khusus wanita Bandung Jawa Barat mengadakan beberapa program pembinaan, naun dilihat dari program pembinaan yang dijalankan walaupun memiliki program ketrampilan dan lain-lain namun tidak memeberikan perhatian khusus mengenai sifat dasar wanita seperti ke-lemah lembut-an, penyaluran rasa sayang kepada anak-anak serta program-program lain yang tidak bisa secara general disamakan dengan lembaga pemasyarakatan umum.

\section{Program Pembinaan}

Pembinaan bertujuan agar ketika narapidana setelah telah menyelesaikan masa pidananya diharapkan tidak akan mengulangi perbuatannya (kejahatan) dan dapat hidup bermasyarakat secara wajar dan dapat berpartisipasi didalam pembangunan. Oleh karena itu maka setiap narapidana di dalam Lembaga Pemasyarakatan dibina agar dapat menggali potensinya dan mengembangkannya menjadi narapidana yang baik dan taat kepada hukum, serta menjunjung tinggi nilai-nilai moral sebagai bekal hidup dikemudian hari apabila sudah keluar dari Lembaga Permasyarakatan

Pola pembinaan ini,seperti yang dikatakan oleh Vernon Fox, dalam bukunya 'Introduction of Corection", mengatakan bahwa :

"Proses treatment dicapai melalui beberapa cara. Secara umum ada masa penerimaan dan diagnosis, setelah itu tahanan di tempatkan di program yang sesuai. Kedua, periode penahanan dimana rata-rata 2 dan 1,5 tahun dikarakterisasi melalui penugasan kerja, program sekolah, dan program treatment individu dan kelompok terapi, tergantung pada fasilitas yang dimiliki institusi. Tahap terakhir adalah pembebasan bersyarat atau pembebasan. Selama periode treatment, personil koreksional bekerja dengan tiap tahanan. Pekerjaan mereka mungkin di bagian klasifikasi, edukasi/pendidikan, medis dan perawatan gigi, psikologis/psikiater, konseling individu, terapi kelompok, atau pelayanan lain yang diselenggarakan.”

\section{Program Pembinaan Lapas Wanita dalam Perspektif Pekerjaan Sosial}

Pada banyak lembaga pemasyarakatan di Indonesia baik umum, khusus wanita, hingga Lapas anak-anak ada satu fenomena yang seringkali dijumpai yaitu over capacity atau kelebihan muatan, hal terebut berdampak pula pada pembibing pemasyarakatan yang memiliki tugas seperti pekerja sosial koreksional sulit untuk mengintervensi. Sebagai contoh narapidana di Lembaga Pemasyarakatan Wanita Kelas II A Tangerang hingga tahun 2012 (data 30 Mei 2012) tercatat 362 orang (Napi 304 orang + Tahanan 58 orang), kapasitas yang mampu ditampung Lapas hanya 250 orang. Sehingga terjadi kelebihan kapasitas sampai 102 orang. Over kapasitas masih menjadi masalah pokok, karena kelebihan kapasitas itu, tak pelak menimbulkan sejumlah masalah di Lapas ini. Konsekuensinya, 1 orang petugas Lapas harus mengawasi lebih dari 25 orang narapidana. Jumlah ini jelas jauh dari kondisi ideal (1 dibanding 25).

Kasus tersebut bukan hanya terjadi pada Lapas Wanita Tangerang saja, hal serupa terjadi pula pada Lapas wanita klas IIA Bandung, Lembaga Pemasyarakatan ini telah melebihi kapasitas penampungan atau over capacity seperti yng dilansir dalam website Kementerian Hukum dan HAM, jumlah penghuni Lembaga Pemasyarakatan Wanita Klas IIA, Bandung berjumlah 371 orang, sedangkan kapasitas seharusnya adalah 325 orang.

Dalam hal pembinaan, pekerja sosial sangat berperan penting untuk kembali membantu keberfungsian sosial narapidana wanita, istilah 'pebimbing pemasyarakatan' atau 'wali' dengan kata 
lain dirujuk sebagai definisi lain dari pekerja sosial. Jika dilihat dari perbandingna antara wali dengan narapidana yang ada, dapat dilihat bahwa banyak narapidana yang tidak terawasi dengan baik serta tidak mendapat pembinaan yang baik pula yang akan dikhawatirkan tidak meberi pengaruh apa-apa ketika narapidana telah menyelesaikan masa tahanan pada lembaga pemasyarakatan tersebut.

Pada salah satu metode pekerjaan sosial ada metode Social Grup Work dimana orang-orang yang memiliki 'masalah' yang sama dikumpulkan dalam atu kelompok kemudian mereka akan saling bercerita, bermain serta mendapatkan pesan dan kean dengan cerita orang lain yang berada dalam sau kelompok bersama mereka. Pola social group work ini dapat dimasukkan dalam salah satu pola pembinaan lembaga pemasyarakatan wanita. Hal lain yang dapat menguatkan metode social group work untuk pola pembinaan adalah konep gender, masing-masing individu khususnya wanita akan lebih nyaman untuk bercerita dan lebih terbuka apabila bercerita dengan sesame wanita. Hal ini akan membantu proses social group work, dan apabila dilakukan secara berkala akan berdampak pada diri narapidana kebali lebih merasa diterima dalam kelompoknya.

Selain itu, masalah yang disoroti dalam pola pembinaan narapidana adalah masalah minimnya pembimbing kemayarakatan atau pekerja sosial yang dimiliki lembaga pemasyarakatan,

setelah melihat beberapa fenomen yang dipaparkan diatas aka berikut adalah solusi atas keterbatasan tersebut yang ditawarkan :

1. Optimalisasi sumber daya dari pihak luar, misalnya penyelenggara kegiatan pembinaan dari dinas kesehatan, guru atau ustadz serta stakeholders lain yang mengatur pola pembinaan kerohanian serta petugas Lapas lain untuk tetap membimbing narapidana sekalipun bukan wali dari narapidana tersebut

2. Memaksimalkan peran kementerian hukum dan HAM untuk mendata narapidana yang ada sehingga kaus over capacity tidak terjadi lagi, karena selain mengganggu pola pembinaan hal tersbut akan pula mengganggu hak dari narapidana itu sendiri

3. Selama proses pembinaan, narapidana diajarkan untuk bisa saling memotivai satu sama lain dan diberikan tugas khusus yang bisa merekatkan hubungan antar narapidana.

4. Melakukan assessment tentang pola pembinaan seperti apa yang dibutuhkan dan diingkan narapidana agar mereka dapat berkembang serta kedepannya dapat kembali diterima oleh masyarakat.

\section{Kesimpulan dan Saran}

embaga Pemasyarakatan hadir dikarenakan jumlah tindakan kriminal yang semakin meningkat dari hari ke hari karena bermacam faktor. Konsep lembaga pemasyarakatan meniadakan kata 'penjara' bagi pelaku tindak criminal karena konsep 'penjara' dianggap tidak manusiawi bagi para pelaku yang seharusnya diharapkan dapat kembali hidup bermasyarakat dengan normal selama menjalani masa pembinaan.

Pada setiap lembaga pemasyarakatan pasti memiliki pola pembinaan tersendiri berdasarkan keputusan yang ditetapkan pada UU tentang lembaga pemasyarakatan, misalnya pada lembaga pemasyarakatan wanita klas IIA Bandung, petugas mengharuskan para narapidana wanita bangun pada waktu subuh dan melanjutkan aktivitas olahraga kemudian embersihkan lingkungan sekitar, selain itu pelatihan ketrampilan seperti menjahit dan penyuluhan juga erupakan bagian dari pola pembinaan rutin yang diberikan kepada narapidana lembaga pemasyarakatan wanita.

Peran pekerja sosial dalam isu koreksional adalah sebagai pembimbing atau wali dala pola pembinaan tersebut, naun sayangnya, fenomena di Indonesia banyak Leapas yang melebihi kapasitas, sehingga jumlah wali atau pembimbing lebih sedikit dari jumlah narapidana yang ada.

Saran yang dapat penulis berikan adalah pihak lembaga pemasyarakatan harus lebih memperhatikan narapidana dengan memberikan hak mereka yaitu diberi pola pembinaan yang baik dengan cara memenuhi kebutuhan akan wali atau pendamping pemasyarakatan. Metode social group work dapat diterapkan pula dala proses pembinaan ini karena akan membantu narapidana merasa 
diterima kembali oleh kelompok tersebut dan nantinya diharapkan narapidana akan merasa diterima pula di masyarakat luas yang akan hidup berdampingan dengan mereka kelak.

\section{Daftar Rujukan}

Buku :

Fakih, Mansoer.1997. Analisis Gender dan Transformasi Sosial. Yogyakarta: Pustaka Pelajar. Carney, Louis P. 1980, Corrections Treatment and Philosophy. Prentice-Hall, Inc Englewood Cliffs Wibhawa, budhi dkk. 2010. Dasar-dasar Pekerjaan Sosial. Bandung: Widya Padjadjadran

Rujukan elektronik :

id.wikipedia.org/wiki/Lembaga_Pemasyarakatan diunduh pada 3 November 2014, 11:18

"POLA KOMUNIKASI INTERPESONAL ANTARA PETUGAS, NARAPIDANA DAN

PEMBESUK LEMBAGA PEMASYARAKATAN “http://digilib.unmuhjember.ac.id/POLA

KOMUNIKASI INTERPESONAL ANTARA PETUGAS, NARAPIDANA DAN

PEMBESUK LEMBAGA PEMASYARAKATAN JEMBER diunduh pada 3 november 2014, 22.30

http://id.wikipedia.org/wiki/Interaksi_sosial/ diunduh pada 4 November 2014, 07.00

Jurnal :

Jurnal Info Baru. “ Pola Pembinaan Napi Wanita: Dalam Perspektif Pekerjaan Sosial di Lembaga

Pemasyarakatan Wanita Kelas II A Tangerang”. Volume 10 Agustus 2014

Hasil Penelitian :

Teguh, Santoso, 2013, PERAN PEKERJA SOSIAL DALAM BIDANG KRIMINALITAS(STUDI KASUS DI LEMBAGA PEMASYARAKATAN KLAS II A YOGYAKARTA). (e-book) 